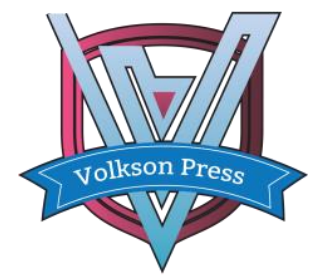

Contents List available at VOLKSON PRESS

Economics \& Management Innovations(EMI)

DOI : http://doi.org/10.26480/icemi.01.2017.427.428

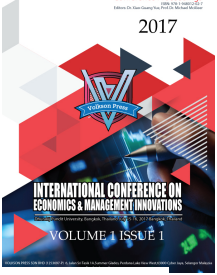

\title{
Discussion on the contract legal risk and precaution in small micro-enterprise
}

\section{Ye Chen}

Wuhan University of Technology, China

Email: 505235793@qq.com

This is an open access article distributed under the Creative Commons Attribution License, which permits unrestricted use, distribution, and reproduction in any medium, provided the original work is properly cited.

\section{ARTICLE DETAILS}

\section{Article History:}

Received 02 october 2017 Accepted 06 october 2017

Available online 11 october 2017

\section{Keywords:}

small micro-enterprise, legal risk of contract, management

\section{ABSTRACT}

In the support of policy from government, small micro-enterprise is developing rapidly. However, due to the neglect of the legal risks of the contract, small micro-enterprise has a shorter life in China than other countries. The aim is to enhance the competitiveness of small micro-enterprise and promote the development of the socialist market economy in China.from the summary of contract legal risk and the current situation of legal risk of small microenterprise contract in China, result that, the establishment of specialized contract management organization and the establishment of internal professional legal counsel system within the micro-enterprise is necessary. This suggestion of preventing the legal risk of contract for small micro-enterprises is proposed.

\section{Summary of legal risks of contract}

\subsection{Definition of legal risk of contract}

Contract law risk is kind of the legal risk ,there are different viewpoints from China and abroad. According to the new Basel capital Accord, legal risk is a special type of operational risk, which includes but is not limited to the exposure of fines, fines or punitive damages arising from regulatory measures and settlement of civil and commercial disputes. The author thinks that the legal risk of enterprise contract is one kind of enterprise legal risk, it refers to the possibility of the contract party to bear legal liability in the whole process of establishment,fulfillment and breach of contract, because of violating the stipulation of law or contract.

\subsection{Characteristics of contractual legal risks}

Firstly, the legal risk of contract is universal.Contract legal risk is dependent on the contract, the contract as one of the main forms of small micro-enterprise transactions, it is ubiquitous in every small microenterprise, thus, the resulting contract legal risk also exists in every a business transactions, with the inevitable universality.

Secondly, the legal risk of contract is uncertain.Small micro-enterprise in the development of foreign countries, the object of the offer is not specific.The choice of trading objects because of their own economic strength and corporate credibility, and other factors, the likelihood of liability to bear the size of the cause the legal uncertainty. The legal risk of this contract will change with the trust degree between the parties and the transaction of each other's own business management model, which has great uncertainty, not everlasting.The author thinks that the factors influencing the legal risk of small micro-enterprise contract are: The comprehensive strength of the counterparty and the particularity of the trading industry.Generally speaking, the higher the overall strength of the trading partner, the smaller the legal risk of the contract arising from the transaction.The particularity of the trading industry also stipulates that the parties to the transaction violate the industry standards should bear the responsibility, resulting in the size of the specific provisions of each trading industry varies.

Finally, the legal risk of contract that we have to deal with are throughout .According to the process of implementing the contract, this risk can be classified as ex ante risk, in the risk and ex post risk, i. e. Contract law risk runs through every process of contract implementation.Ex ante risk refers to the contract in which the small micro-enterprise chooses the transaction object and whether the contract can conclude the risk of success, at this stage which often accompanies the emergence of contracting fault liability. In the risk is that after the contract is established, during the fulfillment, the possibility of a transaction of breach by the other enterprise, that is, the purpose of the contract can be realized.this type of risk is common responsibility for breach of responsibility and the consequent liability arising from tort.Ex post risk, refers to the contract after the completion of the implementation of the possibility of responsibility between the two sides, the common contractual obligations, including notification, assistance, confidentiality obligations, such obligations arising from the responsibility to bear, but also small microenterprise in the transaction of the common legal risk.

To sum up, small micro-enterprise contract legal risk is unavoidable throughout the small micro-enterprise transactions, and this risk due to its uncertainty, need to arouse high attention and precautions.Because of the maturity of the development of the large enterprises, the understanding of the legal risk of contract has already become a system, the small micro-enterprise in the contract legal risk is still in the blank stage in our country,which need further research.

\section{The development and present situation of small micro-} enterprise

Under the background of the State Council vigorously advancing the"public Entrepreneurship and innovation", small micro-enterprise in China are developing rapidly.According to the State Administration for industry and commerce in the third quarter of 2015, the new small microenterprise annual questionnaire analysis, Small micro-enterprise are more active to stimulate economic growth, especially play an important role in the promotion of high-efficiency graduates and unemployed workers in re-employment.The local government reduces the registration threshold, develops the assisting development measures and organizes the supporting activities, which provides a good opportunity and platform for the development of small micro enterprises.Small micro-enterprise gradually occupies an increasingly important position in our socialist market economy, because it become the new force of development, the main channel of employment and the important source of innovation.

Due to some of their shortcomings, the problems and risks in the Small micro-enterprise are increasingly highlighted.Firstly, the legal risk of external contract is the legal risk of small micro-enterprise that comes from the contract of foreign economic intercourse.Small micro-enterprise are implemented with the encouragement of government policy, and the dependence on the government is stronger than others.It is precisely because the government reduces the registration threshold, thus the emergence of a large number of "one dollar" registered companies,Such companies are struggling with the weakness of financial strength and difficulties in financing, at the same time the small micro-enterprise have 
received much less offer opportunities than other large enterprises because of the low opening rate, the capital operation, the talent introduction of the competitiveness is far from the mature large enterprises which have developed, the company's operating development accounted for an important proportion of contract exchanges. Relying solely on government tax exemption and lowering threshold to gain advantage is not enough to prevent small micro-enterprise external contract legal risk.Second, internal contract legal risk. Due to the scarcity of resources, lack of professional legal personnel and accountants the risk of internal human resources management and enterprise management in the Small micro-enterprise is greater than large enterprises.The development of market economy is the process of continuous contract and fulfillment of contract between equal subjects,so in the development of an enterprise, the control of enterprise contract is particularly important.For small micro enterprises in the side in the legal risk of contract ,is lack of specialized enterprise legal system and awareness of the contract to the formation,which defaults other risks are unprepared, thus greatly exacerbated the enterprise development become more difficult.

In addition, according to the survey data, the average life expectancy of European and American Enterprises is 40-50 years, the average life expectancy of Japanese and Korean enterprises is also about 20-30 years, and the average life expectancy in China is only about $7.3 \%$, A large proportion of small micro-enterprise have lower life expectancy. In China's annual collapse of enterprises, small micro-enterprise also occupy a very high proportion, small micro-enterprise survival has faced a severe test.

It is based on the important position of small micro-enterprise in China's market economy and the current crisis, to strengthen the contract legal risk awareness and to establish a precautionary strategy is a pressing issue. In order to promote the small micro-enterprise to fully exert their function of driving the economy, the government must focus on the legal risk of contract. In order to overcome the limitation of their own conditions, small micro-enterprise themselves also should attach great importance to the construction of the legal risk system of their contract.

\section{The suggestion to prevent the small micro enterprise contract legal risk}

The advantage of small micro-enterprise is the support of its government policy, such as tax Relief and fund support, which comes from the external economic pressure reduction, and its own internal strength is weaker. Because of the limitation of their own size and capital, most small microenterprise can not invest too much in the construction of enterprise legal system, and also because of lack the understanding of the legal risks of the contract,cause a series of legal problems. In order to guard against the legal risk of small micro-enterprise contract, the author thinks that the strategy of coping can be found in the following points.

\subsection{The establishment of specialized contractual management organizations.}

The coping strategy stems from the American NCMA (the National Contract Management Association), the organization is a professional organization,which provide professional management and legal analysis for its members ' contracts. At present, there is no such organization in most countries ,especially in Asian countries.The author thinks, should establish such an organization: Members can voluntarily submit their own contract, and then through the organization professionals according to law and industry rules, make a professional contract legal risk analysis report.This report needs to cover the analysis of the legal risks of the contract from the formation to fulfillment of the entire process of default, and most important is to provide professional legal guidance advice on risk to mitigate this risk.Because of this organization's demanding is professionalism and high credibility, it also should provide professional risk analysis to the members while the confidentiality of contracts,so such organizations should rely on the government,This requires more exchanges and cooperation between countries.

Secondly, the object of such organizations should be limited to small micro-enterprise with very weak qualifications.Small micro-enterprise because of its own ability to restrict, in the competition in the weak position, even if the tax and the funds of the external factors such as preferential treatment, do not solve the internal legal risks of the contract, it is not in contact with large enterprises in an equal confrontation status.The emergence of this management organization can let small micro enterprises recognize the importance of corporate contract legal risks, use legitimate means to safeguard their rights, and avoid falling into the "trap" of large enterprises.

\subsection{The establishment of professional legal counsel system within small micro-enterprise}

Small micro-enterprise do not need to have a sound internal management organization, so the majority of small micro-enterprise will be limited funds in the introduction of talent, accounting risk and management risk, but for their own internal professional legal risk of a few inputs, not even.Therefore, for the small micro-enterprise capable of having a professional legal counsel system, at least there should be professional legal personnel, and analysis of the contractual risks.The author thinks that the Legal counsel system should be mandatory and compared with the small micro-enterprise with weak qualifications in the precautionary strategy, it should make a distinction between the small micro-enterprise and the strength of it. Under the boundaries of small microenterprise,such as micro-enterprise, family workshops, self-employed households, belonging to the organization of the object, by the abovementioned organizations to provide contract legal risk reporting, the boundaries of small micro-enterprise, such as small enterprises, the enterprise must be arranged in the personnel to determine professional legal personnel.

To sum up, the author's view is that in every small micro enterprises to establish the legal risk of the contract to guard against consciousness, for different small micro enterprises, adopting different system design, the establishment of this system must be mandatory, so it is beneficial to small micro-enterprise to make full use of government policy to improve their competitiveness, and contribute to the socialist market economy.

\section{Conclusion}

Public entrepreneurship, the call for innovation to let more people embark on the path of independent entrepreneurship, government policy to support the development of small micro-enterprise to provide a lot of convenience, small micro enterprises should make full use of their advantages, seize the opportunity to strengthen the corporate internal contract law risk awareness, the establishment of corporate contract legal risk system, by reducing the legal risk of contract to enhance their competitiveness, minimizing the likelihood of loss caused by the long-term development of enterprises. The government, while giving economic support, should also provide professional legal support to small microenterprise in need of help, and promote small micro enterprises to become bigger and stronger.

\section{Reference}

[1]Gao Qilin. Research on legal risk of enterprise contract:Modern commercial law.

\section{[2] Junhui Huang,Company law:Beijing, Law Press,( 2009).}

[3]QianyongXu .Operational practice of corporate legal risk management: Beijing,Law Press, (2011).

[4]Yuksel,Ozlemmekehan,Managing Supply Contract and Inventory Riskina Supply Chain Stanford University.(2003).

[5] Shaobin Huang, XuZhang,Yanhua Shang,Research on the legal risk and coping strategies of SME contract:Journal of Hunan Finance and Economics Institute(2012).

[6] Xiaofeng,Chen,China Forbes Ma list:Beijing,China Economic Press, (2009),p.135.

[7]Simon R I. The suicide prevention contract: clinical, legal, and risk management issues. Journal of the American Academy of Psychiatry and the Law, 1999, 27(3): 445-450.

[8]Richard Moorhead, Steven Vaughan,Legal Risk: Definition, Management and Ethics(2015).

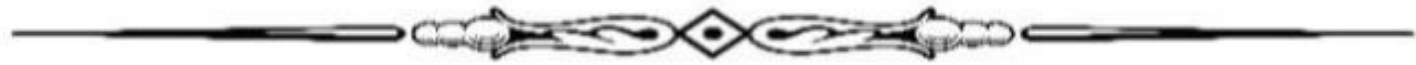

